\title{
Attenuated osteoarticular phenotype of type VI mucopolysaccharidosis: a report of four patients and a review of the literature
}

\author{
Agnieszka Jurecka • Ekaterina Zakharova • Vera Malinova • \\ Elena Voskoboeva • Anna Tylki-Szymańska
}

Received: 26 September 2013 / Accepted: 18 October 2013 / Published online: 13 November 2013

(C) The Author(s) 2013. This article is published with open access at Springerlink.com

\begin{abstract}
Mucopolysaccharidosis type VI (Maroteaux-Lamy syndrome, MPS VI, OMIM 253200) is caused by mutations in the gene coding for $N$-acetylgalactosamine-4-sulfatase (4sulfatase, arylsulfatase B, ARSB, EC 3.1.6.12), a lysosomal enzyme involved in the degradation of dermatan sulfate (DS). The clinical presentation of MPS VI varies greatly with respect to age of onset and rate of disease progression. This report focuses on the attenuated form of MPS VI, which can go unrecognized for years and often presents with atypical signs or symptoms. We described a cohort of MPS VI patients $(n=4)$ heterozygous for the p.Y210C mutation who had a significant osteoarticular involvement at the onset of their disease and who were diagnosed years or even decades later.
\end{abstract}

\footnotetext{
A. Jurecka $(\triangle)$

Department of Medical Genetics, The Children's Memorial Health Institute, Al. Dzieci Polskich 20, 04-730 Warsaw, Poland

e-mail: ajurecka@gmail.com

E. Zakharova $\cdot$ E. Voskoboeva

Department of Inherited Metabolic Diseases, Research Center for Medical Genetics, Moscow, Russia

V. Malinova

Department of Pediatrics and Adolescence Medicine, General

University Hospital, Prague, Czech Republic

V. Malinova

First Faculty of Medicine, Charles University, Prague, Czech Republic

A. Tylki-Szymańska

Department of Pediatrics, Nutrition and Metabolic Diseases, The

Children's Memorial Health Institute, Warsaw, Poland

A. Jurecka

Department of Genetics, University of Gdansk, Gdansk, Poland
}

We have also reviewed the literature $(n=36)$. Two types of attenuated MPS VI phenotypes could be distinguished: osteoarticular and cardiac. The majority of MPS VI patients reported so far as relatively attenuated presented with an essentially osteoarticular phenotype associated with the p.Y210C mutation. Patients homozygous for the p.R152W mutation presented with a cardiac phenotype, which, despite fulfilling the generally used criteria for attenuated phenotype, may lead to fast disease progression and abrupt death. The knowledge of natural history and genotype-phenotype correlation may help in developing a tailored therapy potentially using enzyme replacement therapy with substrate reduction therapy or chaperones.

Keywords Attenuated phenotype - Cardiac phenotype · Genotype-phenotype analysis · Maroteaux-Lamy syndrome · Mucopolysaccharidosis type VI · Osteoarticular phenotype

\section{Introduction}

Mucopolysaccharidosis type VI (Maroteaux-Lamy syndrome, MPS VI, OMIM 253200) is an inherited metabolic disease caused by a deficient activity of $N$ acetylgalactosamine-4-sulfatase (4-sulfatase, arylsulfatase B, ARSB, EC 3.1.6.12), a lysosomal enzyme involved in the degradation of dermatan sulfate (DS) [1,2]. The clinical presentation of MPS VI varies greatly with respect to age of onset and rate of disease progression. Descriptive classification systems have described patients' phenotypes as severe (with early onset of symptoms and fast progression), attenuated (with later onset, slower disease progression, and variable clinical presentation), and intermediate $[1,3]$. Especially in attenuated phenotypes, a definite diagnosis may be delayed 
for years because early symptoms are difficult to recognize for physicians not familiar with the disease, since the disease progresses silently over decades.

The incidence rates for this rare disease vary in the literature between 0.05 [4] and 2.3 [5] diagnosed MPS VI patients per 100,000 live births. Allele frequencies of the different mutations are very low, and most mutations are unique to individual families, except for a high prevalence of p.R152W mutation in Eastern European population [6].

This report focuses on the less severe form of MPS VI. The objective of this article is to show the existence of significant differences between so-called attenuated patients and to highlight the need of close cooperation of different specialties in order to recognize the disease early. The knowledge of natural history and genotype-phenotype correlation may also help in developing a tailored therapy.

\section{Patients and methods}

\section{Patient enrollment and data collection}

The lists of diagnosed MPS VI patients were provided by seven diagnostic centers for MPS VI in Central and Eastern Europe (Warsaw, Prague, Vilnius, Minsk, Riga), Russia (Moscow), and Kazakhstan (Almaty). Out of these patients, only patients with the less severe form of MPS VI were included in our study.

All patients were naïve to enzyme replacement therapy (ERT) at the time of the study.

\section{Ethical consideration}

The protocol was approved by the Human Subjects Institutional Review Board at the Children's Memorial Health Institute. Written informed consent had to be provided by the parents or legal guardians. All patients and/or their families provided written consents about using their photos.

\section{Results}

Patient population

The main demographic and clinical characteristics of all patients in our series are shown in Table 1. All of the patients were Caucasian, and no sex predominance was seen. No consanguinity between parents was recorded.

\section{First clinical features and disease progression}

For all four patients, the age of first symptom onset ranged from 5 to 8 years (median 8 years). The most common first sign to appear was decreased joint range of motion of large joints of the upper and/or lower limbs. The most commonly affected joints were hips, which resulted in hip pain with difficulty in walking and stair climbing. The first misdiagnoses in these patients were Perthes disease, hip dysplasia or osteochondrosis. In addition to the joint problems, some of the patient cohort reported features such as recurrent rhinitis, impaired hearing, hydrocephalus, and in the case of older patients, spinal cord compression.

Within the disease course, the patients developed other disease manifestations such as skeletal abnormalities (Figs. 1 and 2), growth retardation, and spinal cord compression.

Joint stiffness was reported in all patients. It was located mainly in the shoulder and hip joints or other large joints of the upper and/or lower limbs. It was intense and significantly impaired the quality of the patient's life leading to consultations by orthopedic surgeons. Typical for MPS contractures of fingers (so-called claw hands) were also observed decreasing the function, efficiency, and skills of the hands.

At the time of the study, the eldest patients were 45 and 40 years of age.

\section{Delayed diagnosis}

Following the onset of signs and symptoms, MPS VI diagnosis occurred after 9 years of age (range 9-45 years, median 24 years) with median delays 17.5 years.

\section{Literature review}

\section{Clinical phenotypes}

The results of the literature review are presented in Table 2, which includes only reports with clinical data $(n=36)$. The review of the literature allowed distinguishing two types of attenuated MPS VI phenotypes: osteoarticular and cardiac.

In a majority of reported patients, a relatively attenuated phenotype meant an essentially osteoarticular phenotype. These patients initially presented with bone and joint symptoms, especially pain and stiffness in the joints, joint contractures, and hip and back pain. At some point, most of these patients developed serious manifestations of the disease including joint degeneration, sleep apnea, a decrease in pulmonary function, reduced endurance, cardiac valve disease, and skeletal complications including carpal tunnel syndrome and hip disease.

Unlike the majority of reviewed patients, patients homozygous for p.R152W mutation showed a significantly different clinical phenotype with predominance of cardiovascular manifestations $[7,8]$. 
Table 1 Clinical, biochemical, and molecular data of MPS VI patients heterozygous for p.Y210C mutation

\begin{tabular}{|c|c|c|c|c|c|c|c|}
\hline $\begin{array}{l}\text { Case number } \\
\text { (country, } \\
\text { current age) }\end{array}$ & $\begin{array}{l}\text { Age at onset of } \\
\text { symptoms/age } \\
\text { at diagnosis } \\
\text { (years) }\end{array}$ & $\begin{array}{l}\text { Symptoms } \\
\text { at onset }\end{array}$ & $\begin{array}{l}\text { Other symptoms } \\
\text { before MPS VI } \\
\text { diagnosis }\end{array}$ & $\begin{array}{l}\text { Misdiagnosis/ } \\
\text { initial } \\
\text { diagnosis }\end{array}$ & $\begin{array}{l}\text { Extraskeletal } \\
\text { involvement } \\
\text { during the } \\
\text { disease course }\end{array}$ & $\begin{array}{l}\text { ARSB } \\
\text { activity }^{\text {a }}\end{array}$ & Genotype $^{b}$ \\
\hline 1 (Czech Republic, 47) & $10 / 45$ & $\begin{array}{l}\text { DW, HP, } \\
\text { JS, RR }\end{array}$ & CFF, GR, SK & $\begin{array}{l}\text { Hip dysplasia, } \\
\text { Perthes disease }\end{array}$ & $\begin{array}{l}\mathrm{CH}, \mathrm{IH}, \mathrm{M}, \mathrm{SCC}, \\
\mathrm{UH}, \mathrm{HC}\end{array}$ & 10.8 & $\begin{array}{l}\text { p.R160X/ } \\
\text { p.Y210C }\end{array}$ \\
\hline 2 (Russia, 40) & $8 / 38$ & JS & $\begin{array}{l}\text { DW, HP, HC, } \\
\text { SCC }\end{array}$ & $\begin{array}{l}\text { Chondrodysplasia, } \\
\text { osteochondrosis }\end{array}$ & $\mathrm{CFF}, \mathrm{HC}, \mathrm{SCC}$ & 7.4 & $\begin{array}{l}\text { p.Y210C/ } \\
\text { p.C521Y }\end{array}$ \\
\hline 3 (Belarus, 36) & $8 / 9$ & JS & No & Hip dysplasia & $\begin{array}{l}\text { CFF, DW, HP, } \\
\text { CFF, RR }\end{array}$ & 9.8 & $\begin{array}{l}\text { p.T92K/ } \\
\text { p.Y210C }\end{array}$ \\
\hline 4 (Russia, 20) & $5 / 10$ & JS, RR, IH & No & No & CFF, HC & 9.8 & $\begin{array}{l}\text { p.N262Kfs* } \\
\text { 14/p.Y210C }\end{array}$ \\
\hline
\end{tabular}

$D W$ difficulty in walking, $C F F$ coarse facial features, $C H$ claw hands, $G R$ growth retardation, $H C$ hydrocephalus, $H P$ hip pain, $I H$ impaired hearing, $J S$ joint stiffness, $M$ myelopathy, $R R$ recurrent rhinitis, $S C C$ spinal cord compression, $S K$ skeletal abnormalities, $U H$ umbilical hernia

a ARSB activity in the patients' leukocytes was referred to the mean value of several controls analyzed in the same experiment

${ }^{\mathrm{b}}$ NCBI reference sequence: NM_000046.3 (cDNA considering A of the ATG translation initiation codon as nucleotide +1); NP_000037

\section{Genotype-phenotype correlation}

Mutations associated with an attenuated MPS VI phenotype are presented in Table 3.

Apart from the p.R152W and p.Y210C mutations, other mutations have been reported as associated with attenuated disease progression: p.C192R [9] when present in homozygous state and p.D83Y [10], p.C405Y [10], and p.R434I [10] when present in compound heterozygous states. Osteoarticular attenuated phenotype is predominantly associated with a missense mutation p.Y210C, while cardiac with p.R152W in homozygosity. So far, only one patient homozygous for p.Y210C mutation has been described in the literature, while in the majority of patients, this mutation is present with other mis- or nonsense mutation [11].

\section{Discussion}

One of the first descriptions of mucopolysaccharidosis type VI was probably by the neurologist Nonne [12]. After several investigators indicated heterogeneity of MPS VI based on radiological findings, the patients' size, and longevity [13, 14], McKusick suggested separating a severe form (mucopolysaccharidosis type VIA) from a mild variant (type VIB) [15]. Based on McKusick's classification, the longevity, size, lack of cardiac insufficiency in association with mild cardiac murmurs, lack of abnormality of sella turcica, and the absence of umbilical or inguinal hernia, marked hepatosplenomegaly, and marked corneal opacities warranted the diagnosis of the mild B variant of MPS VI [15]. Apart from severe and attenuated phenotypes, descriptive
Fig. 1 a, b Radiographs of a patient heterozygous for the p.Y210C mutation. Lateral radiographs of cervical spine: (1) reduction of cervical lordosis, (2) narrowing of L3 vertebral body and dislocation of L4 vertebral body (arrows), and (3) thickening of the skull bones

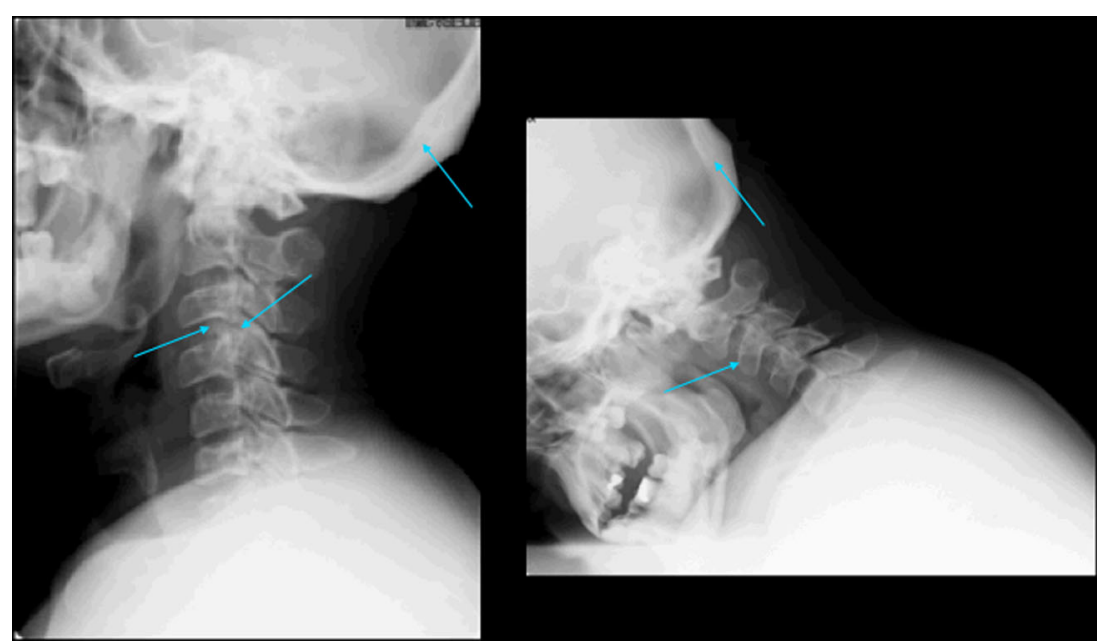




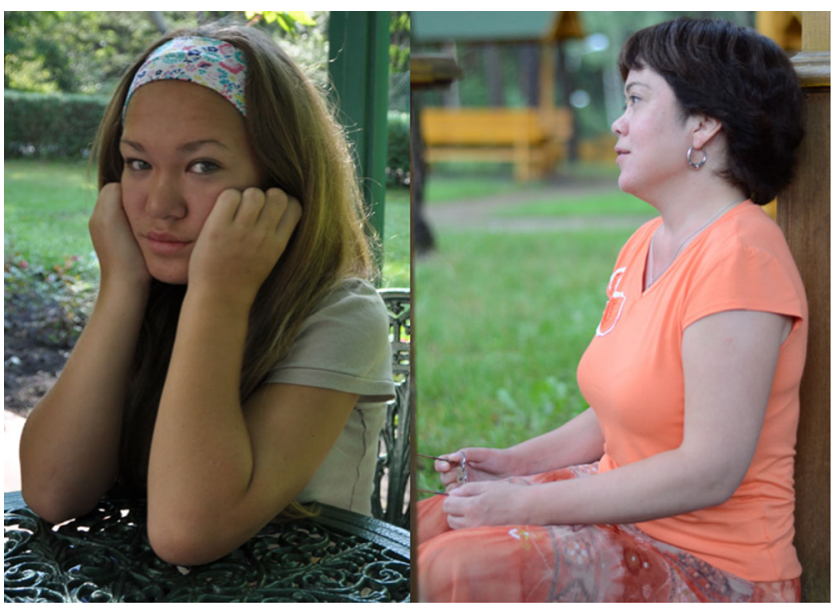

Fig. 2 Pictures of MPS VI patients heterozygous for the p.Y210C mutation

classification systems have also described an intermediate disease form. Other authors suggested other classification systems based on height and urinary glycosaminoglycan (uGAG) levels, the age at the onset of symptoms, patient's height, and the age of death $[16,17]$. In reality, there are no fixed parameters to ascribe a particular patient to a single category, and the decision is subjective depending on physician's experience and knowledge. The relatively attenuated disease form is generally characterized by later onset of symptoms which may not at first appear in a recognized pattern, but when apparent, the milder symptoms may be observed by an alert physician and lead ultimately to diagnosis usually after 5 years of age, but it may be delayed until the second or third decades.

Results from our study and review of the literature allow for distinguishing two types of attenuated MPS VI phenotypes: osteoarticular and cardiac. It is likely that patients with osteoarticular symptoms will be found in either rheumatology or orthopedic clinics. The similarity of attenuated MPS VI to the more commonly seen rheumatological conditions means that patients are often misdiagnosed and there is a delay before the patient's symptoms are attributed to MPS. Patients with a cardiac variant of MPS VI are much more probable to be found in cardiology clinics $[18,19]$. In these patients, cardiac disease progresses silently and ultimately leading to heart failure and does not correspond with the other typical MPS features which are very mild or absent [8]. An advanced valve defect is an indication for valve surgery, which may be beneficial in these patients at an earlier stage of the disease. In both phenotypes, the pathological process seems to be restricted at first to one system only, either osteoarticular or cardiovascular. In the cardiac phenotype, however, it tends to have more serious complications leading to fast disease progression and abrupt death [7].
Despite the utility of communicating with these descriptive categories, it is important to recognize that the symptoms of the disease manifested along a continuum. Using a descriptive classification is very helpful for clinicians; however, it is important to bear in mind its implications. The term attenuated (or used by some slowly progressing) implies a slower disease progression, and it may be perceived that these patients do not require treatment as urgently as severe patients. The truth is that these patients may remain asymptomatic for years with silently (but not necessarily slowly) progressing disease and be recognized in an advanced disease stage when it is too late for any intervention [7]. For this reason, we previously suggested using a term cardiac MPS VI variant to add a sense of urgency as these patients require treatment to be administered prior to the onset of valve disease [8].

The awareness among cardiologists and rheumatologists should be raised so they can play an important role, not only in the management but also in the diagnosis of these patients [18]. The extent of cardiac involvement may be underestimated in patients with mucopolysaccharidosis because of restrictive pulmonary disease and skeletal abnormalities that limit patients' activities [19]. We have previously presented a diagnostic algorithm, suggesting uGAG analysis in any patient with valve disease even in the presence of very mild or untypical disease symptoms [18]. In cases with a high index of suspicion such as those with a positive family history or those with other characteristic features of MPS VI, enzymatic activity should be determined even if uGAG excretion is low. As attenuated patients may still be very difficult to recognize, the delay in diagnosis may make it difficult to influence valve disease with available treatment. Apart from this, we have to bear in mind that the usefulness of enzyme replacement therapy is limited due to the fact that a given enzyme preparation does not have beneficial effects on all aspects of a disorder in the same degree. The effect of ERT alone on cardiac structure and function in MPS patients has been documented in only a few studies [20-23] and larger studies with longer follow-up are still needed. Additionally, clinical studies have shown that many symptoms of mucopolysaccharidoses even after long-term treatment are not anymore reversible. It seems probable that in the future, a tailored combination therapy using ERT with novel therapeutic options such as application of small molecules that either inhibit a key enzyme which is responsible for substrate synthesis (substrate deprivation) or act as a chaperone to increase the residual activity of the lysosomal enzyme (enzyme-enhancing therapy) will be the most effective [24].

By identifying patient's genotype, it may be possible to predict the course of the disease and establish more tailored treatment plan. Patients with the p.Y210C mutation should be 


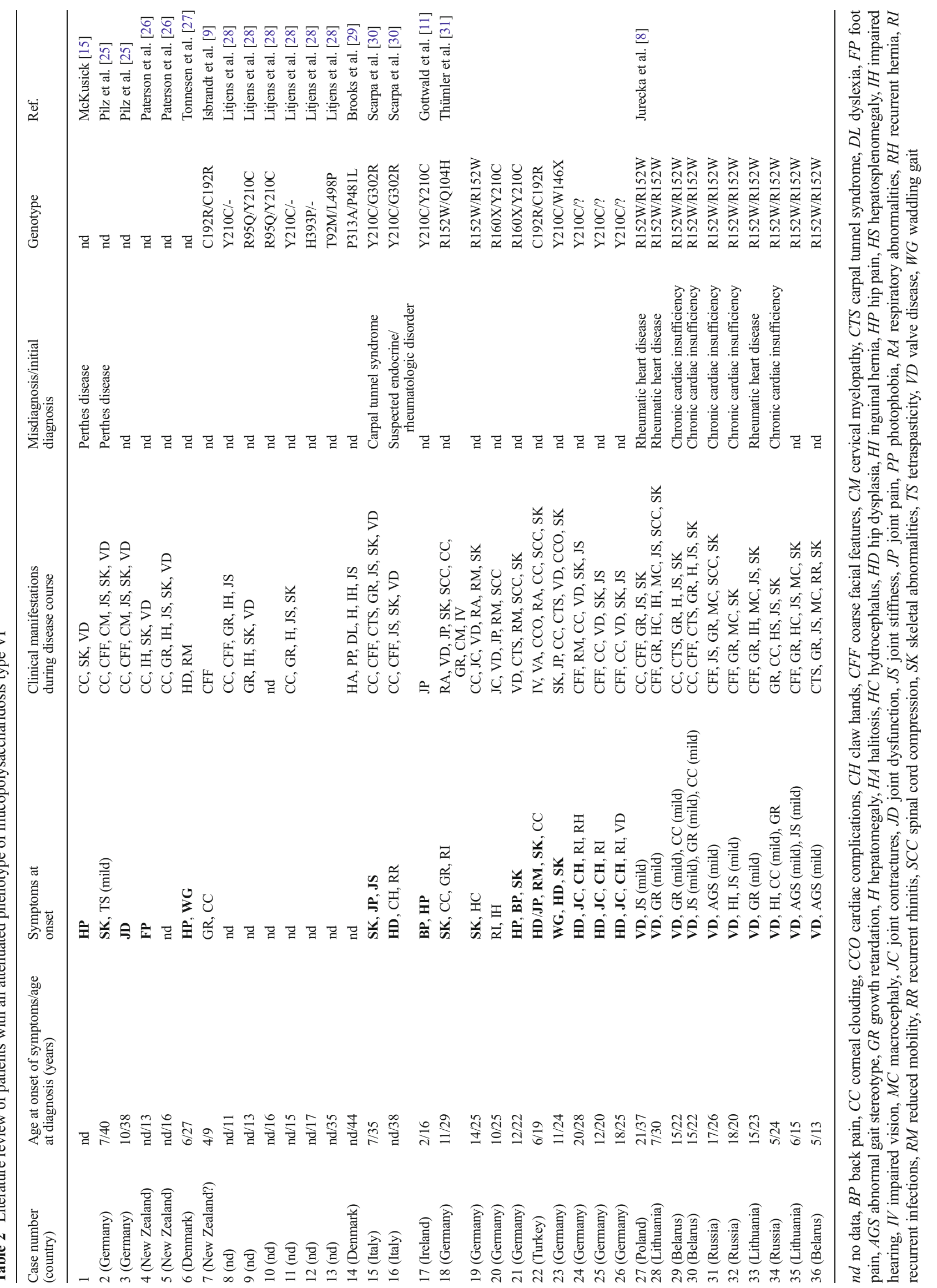


Table 3 Characteristics of the changes in the ARSB gene associated with an attenuated MPS VI phenotype

\begin{tabular}{|c|c|c|c|c|}
\hline Location & $\begin{array}{l}\text { Change at } \\
\text { DNA level }\end{array}$ & $\begin{array}{l}\text { Predicted effect } \\
\text { on amino acid } \\
\text { sequence of the } \\
\text { protein }\end{array}$ & $\begin{array}{l}\text { Type of } \\
\text { mutation }\end{array}$ & Reference \\
\hline Ex. 1 & c. $247 \mathrm{G}>\mathrm{C}$ & p.D83Y & Missense & $\begin{array}{r}\text { Karageorgos } \\
\text { et al. [10] }\end{array}$ \\
\hline Ex. 2 & c. $454 \mathrm{C}>\mathrm{T}$ & p.R152W & Missense & $\begin{array}{r}\text { Voskoboeva } \\
\text { et al. [32] }\end{array}$ \\
\hline \multirow[t]{2}{*}{ Ex. 3} & c. $574 \mathrm{~T}>\mathrm{C}$ & p.C192R & Missense & $\begin{array}{l}\text { Isbrandt } \\
\text { et al. [9] }\end{array}$ \\
\hline & c. $629 \mathrm{~A}>\mathrm{G}$ & p.Y210C & Missense & $\begin{array}{l}\text { Litjens et al. } \\
\text { [4] }\end{array}$ \\
\hline \multirow[t]{2}{*}{ Ex. 7} & c. $1214 \mathrm{G}>\mathrm{A}$ & p.C405Y & Missense & $\begin{array}{r}\text { Karageorgos } \\
\text { et al. [10] }\end{array}$ \\
\hline & c. $1301 \mathrm{G}>\mathrm{T}$ & p.R434I & Missense & $\begin{array}{r}\text { Karageorgos } \\
\text { et al. [10] }\end{array}$ \\
\hline
\end{tabular}

Ex exon

${ }^{\text {a }}$ NCBI reference sequence: NM_000046.3 (cDNA considering A of the ATG translation initiation codon as nucleotide +1 )

covered by a special care team of orthopedists, physiotherapists, and rheumatologists with a plan of rehabilitation, proper early use of orthoses and other support devices, the best determination of time for bone and joint surgery, and application of drug treatments. Patients with the p.R152W should be referred to a cardiologist before the appearance of symptoms from the circulatory system. The mechanism why the p.R152W mutation seems to have a special affinity for the heart valves remains unknown. Perhaps this stems from the specific structure of the valves, and each of these mutations causes different residual enzyme activity. Detecting these differences would explain the process of affecting different organs dependent on the flow dynamics of the substrate.

\section{Conclusions}

1. Based on the literature review, two types of attenuated MPS VI phenotypes can be distinguished: osteoarticular and cardiac, both with a clear genotype-phenotype correlation.

2. The majority of MPS VI patients reported so far as relatively attenuated presented with an essentially osteoarticular phenotype associated with p.Y210C mutation in heterozygosity.

3. The term attenuated should be used with caution as it may imply the slow disease progression and the lack of urgency to treat these patients.
Acknowledgments The authors thank the Polish MPS Society ("Stowarzyszenie Chorych na Mukopolisacharydozę i Choroby Rzadkie") and, in particular, its president, Teresa Matulka, for inviting Lithuanian and Belarusian patients to the society's annual meeting, which allowed us to collect the data and examine the patients. We would also like to express our gratitude to Prof. Węgrzyn and Dr. Ewa Piotrowska (University of Gdańsk, Poland) as well as Dr. Opoka-Winiarska (Medical University of Lublin, Poland) for their critical reading of the manuscript. The authors would like to thank Prof. Nina Gusina (Institute for Hereditary Diseases, Minsk, Belarus) for providing clinical information about her patient.

\section{Disclosures None.}

Open Access This article is distributed under the terms of the Creative Commons Attribution License which permits any use, distribution, and reproduction in any medium, provided the original author(s) and the source are credited.

\section{References}

1. Neufeld EF, Muenzer J (2001) The mucopolysaccharidoses. In: Scriver CR, Beaudet AL, Sly WS (eds) The metabolic and molecular basis of inherited disease. McGraw-Hill, New York, pp 3421-3452

2. Opoka-Winiarska V, Jurecka A, Emeryk A, Tylki-Szymanska A (2013) Osteoimmunology in mucopolysaccharidoses type I, II, VI and VII. Immunological regulation of the osteoarticular system in the course of metabolic inflammation. Osteoarthr Cartilage. doi:10.1016/ j.joca.2013.08.001

3. Valayannopoulos V, Nicely H, Harmatz P, Turbeville S (2010) Mucopolysaccharidosis VI. Orphanet J Rare Dis 5(1):5. doi:10. 1186/1750-1172-5-5

4. Malm G, Lund AM, Mansson JE, Heiberg A (2008) Mucopolysaccharidoses in the Scandinavian countries: incidence and prevalence. Acta Paediatr 97(11):1577-1581. doi:10.1111/j. 1651-2227.2008.00965.x

5. Baehner F, Schmiedeskamp C, Krummenauer F, Miebach E, Bajbouj M, Whybra C, Kohlschutter A, Kampmann C, Beck M (2005) Cumulative incidence rates of the mucopolysaccharidoses in Germany. J Inherit Metab Dis 28(6):1011-1017. doi:10.1007/ s10545-005-0112-z

6. Jurecka A, Piotrowska E, Cimbalistiene L, Gusina N, Sobczynska A, Czartoryska B, Czerska K, Ounap K, Wegrzyn G, Tylki-Szymanska A (2012) Molecular analysis of mucopolysaccharidosis type VI in Poland, Belarus, Lithuania and Estonia. Mol Genet Metab 105(2): 237-243. doi:10.1016/j.ymgme.2011.11.003

7. Jurecka A, Golda A, Opoka-Winiarska V, Piotrowska E, TylkiSzymanska A (2011) Mucopolysaccharidosis type VI (MaroteauxLamy syndrome) with a predominantly cardiac phenotype. Mol Genet Metab 104(4):695-699. doi:10.1016/j.ymgme.2011.08.024

8. Jurecka A, Zakharova E, Cimbalistiene L, Gusina N, Kulpanovich A, Golda A, Opoka-Winiarska V, Piotrowska E, Voskoboeva E, TylkiSzymańska A (2013) Mucopolysaccharidosis type VI: a predominantly cardiac phenotype associated with a homozygosity for $\mathrm{p} . \mathrm{R} 152 \mathrm{~W}$ mutation in the ARSB gene. Am J Med Genet 161(6):1291-1299

9. Isbrandt D, Arlt G, Brooks DA, Hopwood JJ, von Figura K, Peters C (1994) Mucopolysaccharidosis VI (Maroteaux-Lamy syndrome): six unique arylsulfatase B gene alleles causing variable disease phenotypes. Am J Hum Genet 54(3):454-463

10. Karageorgos L, Brooks DA, Pollard A, Melville EL, Hein LK, Clements PR, Ketteridge D, Swiedler SJ, Beck M, Giugliani R, Harmatz P, Wraith JE, Guffon N, Leão Teles E, Sá Miranda MC, Hopwood JJ (2007) Mutational analysis of 105 mucopolysaccharidosis type VI patients. Hum Mutat 28(9):897-903. doi:10.1002/humu.20534 
11. Gottwald I, Hughes J, Stewart F, Tylee K, Church H, Jones SA (2011) Attenuated mucopolysaccharidosis type VI (Maroteaux-Lamy syndrome) due to homozygosity for the p.Y210C mutation in the ARSB gene. Mol Genet Metab 103(3):300-302. doi:10.1016/j.ymgme. 2011.03.024

12. Nonne M (1925) Familiares Vorkommen (3 Geschwister) einer Kombination von imperfekter Chondrodystrophie mit imperfektem Myxoedema infantilis. Dtsch Z Nervenheilkd 83:263-273

13. Rampini S, Maroteaux P (1966) An uncommon phenotype of Hurler's syndrome. Helv Paediatr Acta 21(4):376-386

14. Spranger JW, Koch F, McKusick VA, Natzschka J, Wiedemann HR, Zellweger H (1970) Mucopolysaccharidosis VI (Maroteaux-Lamy's disease). Helv Paediatr Acta 25(4):337-362

15. McKusick VA (1972) Heritable disorders of connective tissue, 4th edn. Mosby, St. Louis

16. Swiedler SJ, Beck M, Bajbouj M, Giugliani R, Schwartz I, Harmatz P, Wraith JE, Roberts J, Ketteridge D, Hopwood JJ, Guffon N, Sa Miranda MC, Teles EL, Berger KI, Piscia-Nichols C (2005) Threshold effect of urinary glycosaminoglycans and the walk test as indicators of disease progression in a survey of subjects with mucopolysaccharidosis VI (Maroteaux-Lamy syndrome). Am J Med Genet A 134A(2):144-150. doi:10.1002/ajmg. a.30579

17. Petry MFG, Nonemacher K, Sebben JC, Schwartz IVD, Azevedo ACM, Burin MG, Rezende AR, Kim CA, Giugliani R, Leistner-Segal S (2005) Mucopolysaccharidosis type VI: identification of novel mutations on the arylsulphatase B gene in South American patients. J Inherit Metab Dis 28(6):1027-1034. doi:10.1007/s10545-005-0020-2

18. Golda A, Jurecka A, Opoka-Winiarska V, Tylki-Szymanska A (2013) Mucopolysaccharidosis type VI: a cardiologist's guide to diagnosis and treatment. Int J Cardiol 167(1):1-10. doi:10.1016/j.ijcard.2012.05.115

19. Golda A, Jurecka A, Tylki-Szymanska A (2011) Cardiovascular manifestations of mucopolysaccharidosis type VI (MaroteauxLamy syndrome). Int J Cardiol 158(1):6-11. doi:10.1016/j.ijcard. 2011.06.097

20. Fesslova V, Corti P, Sersale G, Rovelli A, Russo P, Mannarino S, Butera G, Parini R (2009) The natural course and the impact of therapies of cardiac involvement in the mucopolysaccharidoses. Cardiol Young 19(2):170-178. doi:10.1017/S1047951109003576

21. Braunlin E, Berry J, Whitley C (2006) Cardiac findings after enzyme replacement therapy for mucopolysaccharidosis type I. Am J Cardiol 98(3):416-418. doi:10.1016/j.amjcard.2006.02.047
22. Wraith JE, Beck M, Lane R, van der Ploeg A, Shapiro E, Xue Y, Kakkis ED, Guffon N (2007) Enzyme replacement therapy in patients who have mucopolysaccharidosis I and are younger than 5 years: results of a multinational study of recombinant human alpha-Liduronidase (laronidase). Pediatrics 120(1):e37-e46. doi:10.1542/ peds.2006-2156

23. Okuyama T, Tanaka A, Suzuki Y, Ida H, Tanaka T, Cox GF, Eto Y, Orii T (2010) Japan Elaprase Treatment (JET) study: idursulfase enzyme replacement therapy in adult patients with attenuated Hunter syndrome (mucopolysaccharidosis II, MPS II). Mol Genet Metab 99(1):18-25. doi:10.1016/j.ymgme.2009.08.006

24. Beck M (2007) New therapeutic options for lysosomal storage disorders: enzyme replacement, small molecules and gene therapy. Hum Genet 121(1):1-22. doi:10.1007/s00439-006-0280-4

25. Pilz H, von Figura K, Goebel HH (1979) Deficiency of arylsulfatase $\mathrm{B}$ in 2 brothers aged 40 and 38 years (Maroteaux-Lamy syndrome, type B). Ann Neurol 6(4):315-325. doi:10.1002/ana.410060405

26. Paterson DE, Harper G, Weston HJ, Mattingley J (1982) MaroteauxLamy syndrome, mild form-MPS vi b. Br J Radiol 55(659):805-812

27. Tonnesen T, Gregersen HN, Guttler F (1991) Normal MPS excretion, but dermatan sulphaturia, combined with a mild Maroteaux-Lamy phenotype. J Med Genet 28(7):499-501

28. Litjens T, Brooks DA, Peters C, Gibson GJ, Hopwood JJ (1996) Identification, expression, and biochemical characterization of Nacetylgalactosamine-4-sulfatase mutations and relationship with clinical phenotype in MPS-VI patients. Am J Hum Genet 58(6):11271134

29. Brooks DA, Gibson GJ, Karageorgos L, Hein LK, Robertson EF, Hopwood JJ (2005) An index case for the attenuated end of the mucopolysaccharidosis type VI clinical spectrum. Mol Genet Metab 85(3):236-238. doi:10.1016/j.ymgme.2005.02.008

30. Scarpa M, Buffone E, La Marca P, Campello M, Rampazzo A (2010) Difficulties in diagnosing slowly progressive mucopolysaccharidosis VI: a case series. Journal of pediatric rehabilitation medicine 3:71-75

31. Thümler A, Miebach E, Lampe C, Pitz S, Kamin W, Kampmann C, Link B, Mengel E (2012) Clinical characteristics of adults with slowly progressing mucopolysaccharidosis VI: a case series. J Inherit Metab Dis 35(6):1071-1079. doi:10.1007/s10545-012-9474-1

32. Voskoboeva E, Isbrandt D, von Figura K, Krasnopolskaya X, Peters C (1994) Four novel mutant alleles of the arylsulfatase B gene in two patients with intermediate form of mucopolysaccharidosis VI (Maroteaux-Lamy syndrome). Hum Genet 93(3):259-264 